\title{
Contribution of Community Based Organizations in the conservation of Volcanoes National Park. "Case study of SACOLA in Nyange and Kinigi Sectors, Musanze District, Rwanda.”
}

\author{
EUGENE UWIMANA
}

Ministry of Disaster Management and Refugees, KIGALI, RWANDA

\begin{abstract}
The Community Based Organizations play an important role in the conservation of protected areas. However, they are still at the early stage in Rwanda and require scientific researches to assess their contribution towards National parks conservation. This study was conducted through four cooperatives (Turate ubuhinzi, Ingenzi Kinigi, ANICO, and Muhisimbi) with the sample size of 72 respondents. The data was collected using questionnaires for four months (from July to October 2011) and analyzed using statistical package for social sciences (SPSS), version 16.0. The study was aimed at assessing the contribution of community based organizations to the conservation of Volcanoes National Park, focusing on SACOLA activities in Nyange and Kinigi Sectors, Musanze District. The results indicated that people in the study area conduct many activities but crop production is conducted at 100\%. Concerning the activities of SACOLA, the results show that $81.9 \%$ of population have already benefited from employment (buffalo wall construction and maintenance, guides in community tourism, porters, etc.). The output from Wilcoxon Signed Ranks Test showed that 55\% have decreased their frequencies to go into the park. The same test shows that (11\%) respondents have increased their frequencies to enter the park. The study showed also that 33\% did not change their attitude towards the use of VNP resources. Referring to the statistical analysis at ( $p=.000)$, there is a significance statistical difference between the frequency of going into the park before and after SACOLA activities. There was also an association ( $P=0.026$, Pearson ChiSquare) between satisfaction with SACOLA activities and the probability of going into the park. From these results, the population is that they are beneficiaries of SACOLA at 100\% and they are informed about its activities, and $65.3 \%$ recognized to be satisfied at a very high level, while $19.4 \%$ of respondents mentioned not to be satisfied. Finally, the results show an improvement in conserving Volcanoes National Park since the creation of SACOLA in 2004, and conclude that the contribution of Community Based Organizations is positive and recommend that more effort is needed to maximize the community involvement and also recommend further researches in the same field.
\end{abstract}

Key words: VOLCANOES NATIONAL PARK CONSERVATION; COMMUNITY BASED ORGANIZATION; RWANDA 


\section{Introduction (Heading 1)}

\section{A. Background}

One of the greatest challenges facing humanity in $21^{\text {st }}$ century is how to make natural resource conservation compatible with community development. Despite their long history of interaction with ecosystems, neighboring communities have contributed to endangering their equilibrium through the incompatibility between conservation and their productive practices (Juan et al., 2003).

In the 1970s, conservationists realized that many conservation efforts around the world were failing in their mission of wildlife conservation (Hackel, 1999) and they blamed the failure on the lack of support for conservation by local people. The community conservation was then initiated as an approach to win people as supporters of conservation efforts rather than being hostile to wildlife conservation (Hulme\&Murphree, 2001).

The approach of community conservation came as a counter narrative to the fortress approach and has two elements: to allow people in and around protected areas to participate in the management of conservation resources and the linkage of conservation objectives to local development needs. Besides the fact that community conservation provided an innovation with regards to the need of conservation, it also fitted the discourse of development and foreign aid policy (Adams \& Hulme, 2001).

In Rwanda as it is shown in the park management plan of Volcanoes National Park in 2005, it is stated that the primary aim for incorporating community conservation in the park management is to increase support for the park and wildlife conservation among the surrounding communities (ORTPN, 2005).

Since the establishment of ORTPN in 1974, there has never been any structure to demonstrate that conservation contributes to the development of the population (ORTPN, 2005). In the same perspective, there was a lack of mechanisms to resolve conflicts such as those resulting from damage caused by wild animals. Before the initiation of community conservation department in the Office Rwandais du Tourisme et des Parcs Nationaux (ORTPN) and at the PNV level, the environmental education activities by the park staff were supported by community initiatives implemented by different conservation NonGovernmental Organizations.

The Community Based Organizations (CBOs) plays a major role in the conservation of the Park. Among them there are SACOLA (Sabyinyo Community Livelihood Association), Solidarity Fund, ANICO, FAV, FECAR, etc, (Rutagarama et al., 2008). Sabyinyo Community Livelihoods Association, SACOLA, is a non-profit-making association governed by the law $n^{0} 2^{0} / 2000$ of july26, 2000 relating to the non-profit making associations. It was created in 2004 by the population of the former Kinigi District surrounding the Volcanoes National Park with the assistance of the Rwanda Office of Tourism and National Parks (ORTPN), the International Gorillas Conservation Program (IGCP), the government authorities of surrounding Sectors and former Kinigi District. The association started with 34 founder members presenting the rest of the population of Sectors surrounding Volcanoes National Park. SACOLA Association was created within a framework of conservation of Volcanoes National Park in order to help the surrounding population to initiate development activities for improving their livelihoods while at the same time limiting the threats to conserving Volcanoes National Park in general and maintain gorillas in particular (SACOLA, 2009).

In addition to that, the first luxury ( $\$ 700$ per night) community lodge was constructed at the base of Mt. Sabyinyo, PNV and opened for business in August 


\section{Yinternational Research Journal}

p-ISSN 2202-2821 e-ISSN 1839-6518 (Australian ISSN Agency)

2007. The lodge is owned by SACOLA (Sabyinyo Community Livelihoods Association) who have granted a 15 year lease to a private company to operate the business. SACOLA membership extends to those in cells adjacent to the park in Kinigi and Nyange sectors, a total of approximately 33,000 beneficiaries. A committee of 11 members decides on projects to spend profits on and have so far prioritized road improvements, building houses for marginalized members of the community, water tanks, schools and health centres. Other benefits include employment, with $70 \%$ of jobs currently filled by local people. (IGCP, 2011).

\section{B. Problem Statement}

The term community conservation embraces "principles and practices that argue that conservation goals should be pursued by strategies that emphasize the role of local residents in decision-making about natural resources"(Adams \& Hulme, 2001). Since the creation of Volcanoes National Park in 1925, It has lost about a half of its original size (Plumptre \& Williamson, 2001).

In Rwanda the Community Based Organizations have been created some years ago focusing on conservation. Rutagarama et al. (2008) said that there was the creation of a community conservation unit in 2003 and revenue sharing in 2005. SACOLA was launched in 2004 and the target population or membership was the entire population in cells adjacent to the park in Kinigi and Nyange sectors with the main objective conservation and livelihoods. There is no research already conducted to assess the success of SACOLA, to know if the all concerned beneficiaries (local population from Nyange and Kinigi Sectors) are aware of what it is being done by the association, but also to know if the activities introduced by SACOLA to limit the illegal activities against the park have reduced the influence of concerned population on VNP resources.
Vol. 7 No. 12017

82800701201704

\section{Main objective of the study (Heading}

2)

The main objective of the study is to assess the contribution of community based organizations to the conservation of Volcanoes National Park, case study of SACOLA in Nyange and Kinigi Sectors.

\section{Specific objectives}

1. To identify the economic activities and services introduced by SACOLA in the study area.

2. To determine the impact of SACOLA initiated activities and services to avoid illegal activities on VNP.

\section{E. Research hypothesis}

1. H0: There is no statistical difference between the frequency of going into the park before and after SACOLA activities.H1: There is a statistical difference between the frequency of going into the park before and after SACOLA activities.

$2^{\circ} \mathrm{H0}$ : There is no association between satisfaction with SACOLA activities and the probability of going into the park. H1: There is an association between satisfaction with SACOLA activities and the probability of going into the park.

\section{F. Significance of the study}

The VNP shelters a high number of fauna and flora Endemic species. It was created in 1925 and was the first national park in Africa under the name of "Park National Albert" with its main goal the protection of the last mountain gorillas. Some community members have benefited directly from the park through direct employment as park rangers, trackers and guides. Others have received regular income from tourism as porters, and through selling of arts and crafts, honey and other products to tourists. (Plumptre et al.2003). 
A large number of Community Based organizations (CBOs) exist in the area surrounding Volcanoes National Park. The main orientation for many of them is the park conservation via livelihood improvement. So this study will show the understanding of the local population as the beneficiaries or members of SACOLA on its different activities. It will show how much people are satisfied through different goods and services offered by SACOLA and see how much it contributes to VNP conservation.

This study will be helpful to all stakeholders involved into parks conservation. It shows to RDB, to different NGOs, especially SACOLA staff and other CBOs the image of local community involvement into VNP conservation.II.

\section{Methodology}

The research was carried out in two Sectors of Musanze District namel Kinigi and Nyange, but focusing on four cooperatives directly or indirectly supported by SACOLA. The two Sectors were chosen purposively, the reason is that the entire population from those Sectors is considered as the only beneficiary or member of SACOLA. The study was limited to some activities of SACOLA and its contribution to the Volcanoes National Park conservation. The four cooperatives concerned with the study are: Muhisimbi, Turate ubuhinzi, Ingenzi Kinigi and ANICO and they are the only under SACOLA support.

The methodology used during this study is the multistage sampling. The advantage of this method is that the cost and speed that the survey can be done in convenience of finding the survey sample normally more accurate than cluster sampling for the same size sample.

During this study, Musanze District was chosen purposively and constitutes the first stage of the method. After, two Sectors Kinigi and Nyange are also chosen purposively and it is the second stage. The entire population from the two Sectors was not concerned in sample making. The four cooperatives working in Kinigi and Nyange were selected purposively and constitute the third stage of sample making. Within the cooperatives, the proportionate sampling was used to determine the sample at cooperative level and the number of women and men according to their total number in each cooperative using the Dagnelie's formula.

\section{Table1: Cooperatives and their members}

\begin{tabular}{|c|c|c|c|}
\hline Cooperatives & Men & Women & \multicolumn{2}{|c|}{$\begin{array}{c}\text { Total } \\
\text { number }\end{array}$} \\
\hline Turate ubuhinzi & 64 & 102 & 166 \\
\hline Muhisimbi & 12 & 5 & 17 \\
\hline ANICO & 18 & 4 & 22 \\
\hline Ingenzi Kinigi & 38 & 7 & 45 \\
\hline Total & $\mathbf{1 3 2}$ & $\mathbf{1 1 8}$ & $\mathbf{2 5 0}$ \\
\hline
\end{tabular}

Using the table of Yamane (1967) as attached in annex 3, the sample (n) is 72 people where the confidence or risk level is $95 \%$ and $\pm 10 \%$ of precision level called also sampling error and degree of variability $(\mathrm{P}=.5)$.

At cooperative level the following formula was used as follows:

$n i=\frac{\mathrm{N} \text { i } * \mathrm{n}}{\mathrm{N}}($ Dagnelie, 2006)

Where as:

$\mathrm{ni}=$ the sample proportion size to be determined

$\mathrm{Ni}=$ the population in the stratum; $\mathrm{n}=$ the sample size; $\mathrm{N}=$ the total population in the cooperatives;

According to the number of members of each cooperative, the sample size at cooperative level was calculated. Also the sample was taken in reference to the number of women and men in each cooperative

Table 2: Sample size at cooperative level

\begin{tabular}{|c|c|c|c|}
\hline Cooperatives & $\begin{array}{c}\text { Total } \\
\text { number }\end{array}$ & Women & Men \\
\hline Turate ubuhinzi & 48 & 30 & 18 \\
\hline
\end{tabular}




\begin{tabular}{|c|c|c|c|}
\hline Muhisimbi & 5 & 1 & 4 \\
\hline ANICO & 6 & 1 & 5 \\
\hline Ingenzi Kinigi & 13 & 2 & 11 \\
\hline Total & 72 & 34 & 38 \\
\hline
\end{tabular}

Using a questionnaire well designed and pre-tested, the respondents were randomly selected using membership lists of cooperatives but respecting the sample size and number of women and men in each cooperative. The data collection took four months, from August to November 2011 and ten questionnaires were filled a day. For the secondary data, the use of KARISOKE and RDB/tourism libraries were useful. The necessary secondary data in this research was the general informations on protected areas at international and national level, the involvement of local communities in parks conservation and the status of illegal activities in VNP. This documentation was necessary in literature review making and results discussion.

The data collected were processed and analyzed using statistical package for social sciences (SPSS), version 16.0.

\section{Findings}

\section{II.1 Demographic information}

Table 3: Sex of the respondents

\begin{tabular}{|l|c|}
\hline Sex & Percentage \\
\hline Male & 52.8 \\
Female & 47.2 \\
Total & 100.0 \\
\hline
\end{tabular}

Table 4: Age of the respondents

\begin{tabular}{|l|c|}
\hline Age (Year) & Percent \\
\hline $71-80$ & 2.8 \\
$61-70$ & 1.4 \\
$51-60$ & 6.9 \\
$41-50$ & 27.8 \\
$31-40$ & 36.1 \\
$21-30$ & 25.0 \\
Total & 100.0 \\
\hline
\end{tabular}

Table 51: Education level of the respondents

\begin{tabular}{|l|c|}
\hline Education level & Percent \\
\hline Secondary & 16.7 \\
primary & 40.3 \\
No education & 43.1 \\
Total & 100.0 \\
\hline
\end{tabular}

II.2 Economic activities of the respondents

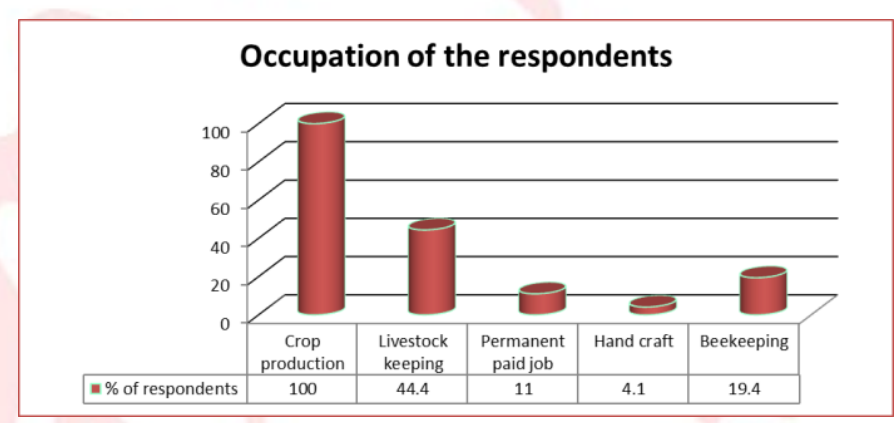

The result shows that agriculture is the main activities which generate a lot of income used to sustain their livelihood.

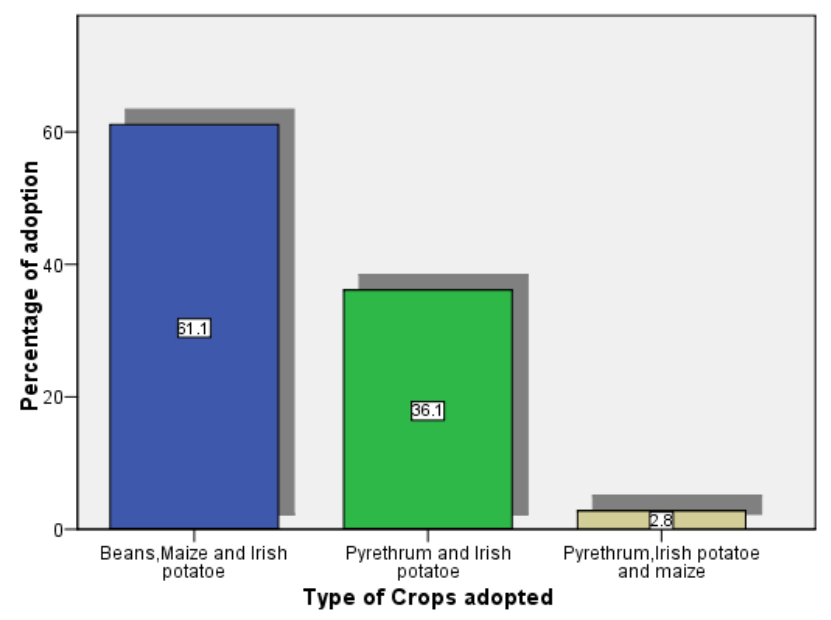

In crop production the main crops grown by people adjacent the volcanoes national park includes Irish potatoes which generate more money and also used for home consumption, pyrethrum is a cash crop in this area.

Table 6: Respondent's mean annual income

\begin{tabular}{|l|c|}
\hline Source of income & $\begin{array}{l}\text { Mean annual } \\
\text { income (Rwf) }\end{array}$ \\
\hline $\begin{array}{l}\text { Additional income from } \\
\text { cooperatives }\end{array}$ & 9555 \\
\hline Income from Irish potatoes & 323583.00 \\
\hline
\end{tabular}




\begin{tabular}{|l|c|}
\hline Income from pyrethrum & 337037.00 \\
\hline Income from Beans & 78289.00 \\
\hline Income from maize production & 63064.00 \\
\hline Livestock annual income & 73333.00 \\
\hline Job paid annual income & 192667.00 \\
\hline Trade annual income & 42000.75 \\
\hline Beekeeping annual income & 119466.00 \\
\hline Handcraft annual income & 20000.00 \\
\hline
\end{tabular}

Different activities are the source of income to the people from Kinigi and Nyange. The table 6 above gives the main activities and the mean income along all the year. The agriculture alone constitute almost a half of the total income with Irish potatoes ( $M=323583$ Rwf), Pyrethrum ( $M=337037$ Rwf), Beans ( $M=78289$ Rwf), and Maize (M=63063 Rwf). Other activities participate by offering respectively ( $M=73333$ Rwf) for livestock, $(M=192667$ Rwf) for permanent paid job, (M=119466 Rwf) for beekeeping, (M=42000 Rwf) for trade, and (M=20000 Rwf) for handcraft.

\section{SACOLA interventions}

The figure below gives different activities of SACOLA and the percentage to which people from the four cooperatives have benefited from.

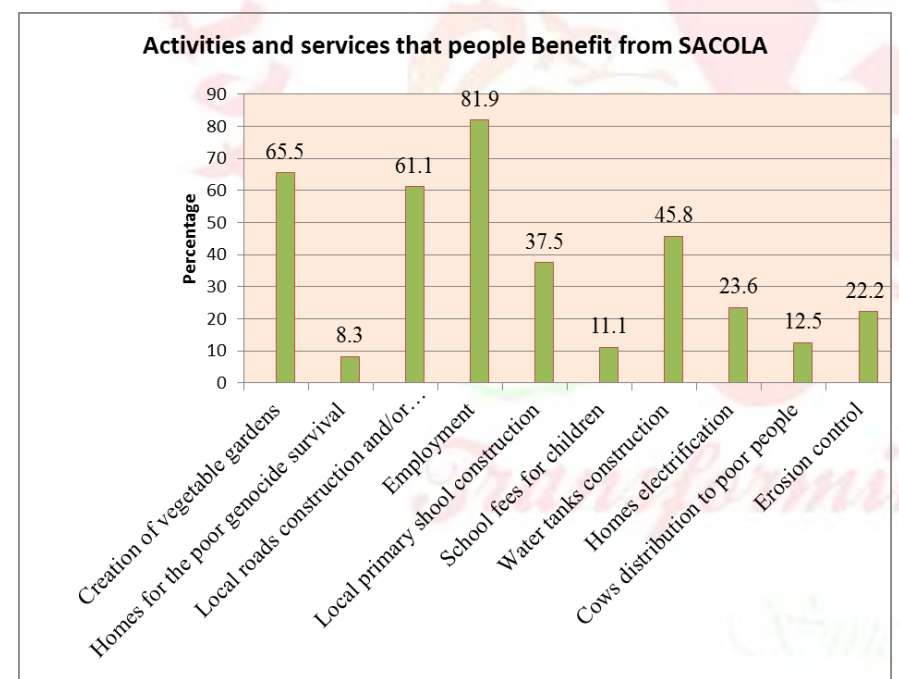

A proportion of $65.5 \%$ respondents stated that they have already benefited from vegetable gardens constructed by SACOLA. Eight point three $(8.3 \%)$ have benefited from houses, whereas $(61.1 \%)$ are benefiting from roads constructed or rehabilitated by SACOLA. However, the majority $(81.9 \%)$ of respondents stated that they benefit from employment (not permanent), whereas (37.5\%) benefit from local primary schools build by SACOLA.

A proportion of $(11.1 \%)$ said to get school fees for their children from SACOLA, whereas $(45.8 \%)$ are using water tanks from SACOLA resources. Twenty three point six (23.6\%) mentioned that they are benefiting from home electrification, twelve point five $(12.5 \%)$ have got cows, while $(22.2 \%)$ of respondents had their soils free from erosion.

Many of the beneficiaries are most of the time employed by SACOLA to participate in buffalo wall and are considered as part time employees. Also, the members of Muhisimbi cooperatives are permanently employed in community walk or community tourism.

The results from IGCP (Rutagarama et al., 2008) shows that SACOLA decided on projects to spend profits on and have so far prioritized road improvements, building houses for marginalized members of the community, water tanks, and schools. It relates also that other benefits include employment, with $70 \%$ of jobs which is currently filled by local people.

\section{III.1 Relationship between SACOLA employment and cooperatives members}

Table 7: Relationship between SACOLA employment and cooperatives members

\begin{tabular}{|l|l|c|c|c|}
\hline \multirow{2}{*}{ Cooperative name } & \multicolumn{2}{|c|}{ Employment } & \multirow{2}{*}{ Total } \\
\cline { 3 - 4 } \multicolumn{2}{|c|}{} & Yes & No & \\
\hline & Turate ubuhinzi & 48 & 0 & 48 \\
\hline ANICO & 5 & 1 & 6 \\
\hline Muhisimbi & 5 & 0 & 5 \\
\hline Ingenzi Kinigi & 1 & 12 & 13 \\
\hline \multicolumn{2}{|l|}{ Total } & 59 & 13 & 72 \\
\hline
\end{tabular}

The table above shows that $81.9 \%$ of all cooperatve members are employed by SACOLA. 
SACOLA help beneficiaries to get employed in buffaloe wall construction and maintenance and are paid according to the number of meters repaired or constructed. They have also an agricultural project supported by SACOLA. Members of ANICO deal with crop-raiding problems and serve as link between Rwanda Development Board and communities, while the members of Muhisimbi are employed as guides for community tourism, and some in cultural center. Ingenzi Kinigi is a new cooperative under SACOLA support and many of its members are not yet getting employment in SACOLA.

\section{Chi-Square Tests}

Table 8: Chi-Square Tests

\begin{tabular}{|c|c|c|c|}
\hline & Value & df & $\begin{array}{l}\text { Asymp. Sig. (2- } \\
\text { sided) }\end{array}$ \\
\hline $\begin{array}{l}\text { Pearson Chi- } \\
\text { Square }\end{array}$ & $\begin{array}{l}60.129 \\
a\end{array}$ & 3 & .000 \\
\hline Likelihood Ratio & 55.544 & 3 & .000 \\
\hline $\mathrm{N}$ of Valid Cases & 72 & & \\
\hline
\end{tabular}

The lower the significance value, the less likely it is that the two variables are independent (unrelated). The significance value for this test $(\mathrm{P}=0.000)$ is less than 0.05 , which explains a significant relationship between the two variables. Normally, to get employed in SACOLA for local communities around VNP, it requires being in one of the cooperatives supported by SACOLA and we have seen that $70 \%$ of jobs is filled by local people (Rutagarama et al., 2008).

\section{2 VNP resources use before and after joining SACOLA}

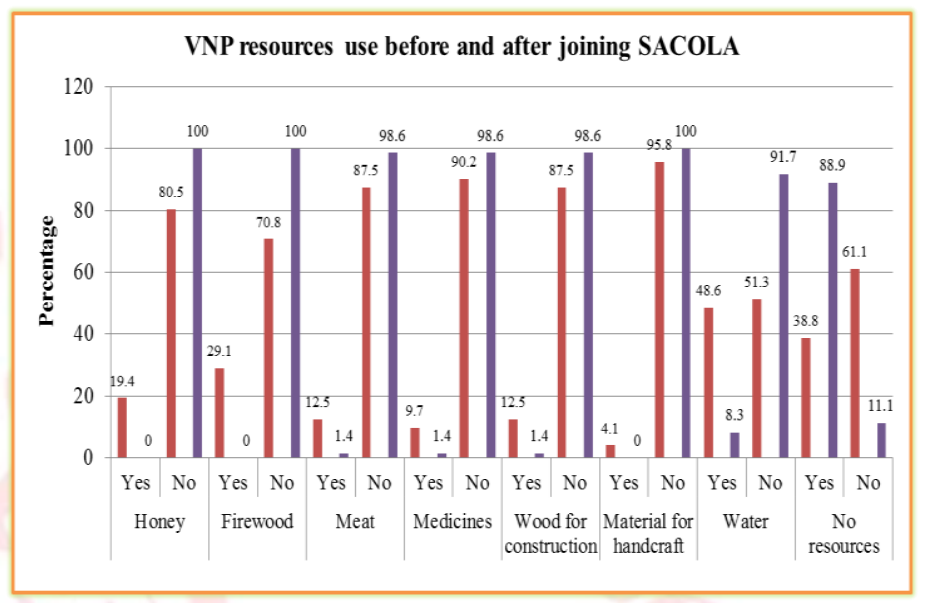

To know if SACOLA reduced the pressure of surrounding population on VNP resources, the questions concerning the resources use before and after the respondents join SACOLA were used. The results as presented by the figure above, (19.4\%) of respondents were using honey before they join SACOLA, while after it was reduced to $(0 \%)$. A proportion of $(29.1 \%)$ was using Firewood before, whereas it was reduced to $(0 \%)$ after. The use of meat from PNV was (12.5\%) before, but the results show that after, it was reduced to $(1.4 \%)$. The medicines was used at $(9.7 \%)$ before, whereas after it was reduced to $(1.4 \%)$. A proportion of $(12.5 \%)$ of respondents was using wood for construction before, but the figure 9 indicates that respondents used it after at $(1.4 \%)$. The material for handcraft was at $(4.1 \%)$ and reduced at $(0 \%)$, while the use of water before joining SACOLA was at $(48.6 \%)$ and $(8.3 \%)$ after. The results show that $(38.8 \%)$ of respondents did not use the resources from VNP before, while $(88.9 \%)$ did not use these resources after. This results show that there has been changes from the resources used before to the resources used after.

Water has been many years ago until now, the resource that has pushed many people to enter the VNP.

Using an example from Volcanoes National Park annual report (2010), the number of people looking for water illegally in VNP was 3320 in 2003, 
increased to 7575 in 2004 , but reduced to 3781 in 2005 and to 1610 in 2006, and 1983 in 2010. This change from 2004 to 2006 is explained by creation of a community conservation unit in 2003 , and the introduction of revenue sharing in 2005. (Rutagarama et al., 2008).

Hitimana et al. (2006) saw also that all water being used by the surrounding communities originates from the Park. Moreover, the majority of the population adjacent to the Park fetches water from the forest especially during dry periods when the seasonal streams dry off.

\section{Wilcoxon Signed Ranks Test}

Table 9: Wilcoxon Signed Ranks Test

\begin{tabular}{|l|l|c|c|}
\hline \multicolumn{2}{|l|}{} & N & Mean Rank \\
\hline Number of times & Negativ & 4 & 27.60 \\
being inside the & e Ranks & 0 & \\
\cline { 2 - 4 } VNP after joining & Positive & 8 & 9.00 \\
SACOLA - & Ranks & & \\
\cline { 2 - 4 } $\begin{array}{l}\text { Number of times } \\
\text { being inside the } \\
\text { park before } \\
\text { joining SACOLA }\end{array}$ & Ties & 2 & - \\
\cline { 2 - 4 } & & 4 & \\
\hline
\end{tabular}

\section{Test Statistics}

\section{Table 10: Test Statistics}

\begin{tabular}{|l|c|}
\hline & $\begin{array}{l}\text { Number of times being inside the } \\
\text { VNP after joining SACOLA - } \\
\text { Number of times being inside the } \\
\text { park before joining SACOLA }\end{array}$ \\
\hline Z & -5.336 \\
\hline $\begin{array}{l}\text { Asymp. Sig. } \\
\text { (2-tailed) }\end{array}$ & .000 \\
\hline
\end{tabular}

The output from Wilcoxon Signed Ranks Test shows that $55 \%$ of SACOLA members have decreased their frequencies to go into the park and this explains a positive impact of SACOLA. It means that they reduced their number to enter inside the park and this explains the reduction of the negative influence of the people on Volcanoes National Park resources. This is supported by the reports by Rwanda Development Board concerning the reduction frequencies on treecutting from 2004 to 2010, and the reduction in number of cases of honey collection from 2006 to 2010 as it is shown in PNV annual report (2010).

The same test shows that $11 \%$ increased their frequencies to enter the park. It seems to be a hard work that SACOLA has to change these people and it is the case but among these people, the way of entering the park is not the same, some of them have entered the park legally and others illegally. The study shows also 33\% respondents that did not change their attitude towards the use of VNP resources. It means that maybe some of them were using those resources before SACOLA, and the test shows that they are still using them at the same frequency. The number of frequency starts by zero in this study, that's why the respondents that mentioned that they have never entered the park have been attributed zero frequency and it explains that some of these 24 respondents did not enter the park before and they did not change their attitude toward VNP after SACOLA.

Referring to the statistical analysis at $(p=.000)$, there is a significance statistical difference between the frequency of going into the park before and after SACOLA activities, and there is failure to accept the null hypothesis.

\section{III.3 Level of satisfaction of the respondents}

The output of cross tabulation showed that out of 8 respondents who are still extracting resources from Volcanoes National Park, 3(37.5\%) are very highly satisfied by SACOLA activities, and while 5 $(62.5 \%)$ are not at all satisfied by SACOLA intervention. Among 64 respondents which are no longer using the resources from the park after, 5 (7.8\%) are satisfied by SACOLA activities at a very low level, $3(4.7 \%)$ at low level and $3(4.7 \%)$ for 
high level, $44(68.8 \%)$ are satisfied at a very high level, and $9(14.1 \%)$ are not at all satisfied.

The results above shows also that the total of (47) $65.3 \%$ of respondents recognized to be satisfied at a very high level, while (3) $4.2 \%$ are satisfied at a high level. The total of $3(6.9 \%)$ respondents recognized to be satisfied at a very low level and 3 (4.2\%) at a low level, while the total of $14(19.4 \%)$ respondents mentioned not to be satisfied.

The research found that some people who are still extracting resources from the park, but they mentioned to be satisfied by SACOLA activities. It means that their movements towards VNP are not influenced by the level at which they are benefiting from SACOLA activities, even though they are satisfied, they continue to enter the park.

Further research by Makambo, (2009) mentioned that reason some people do not change their mind towards Volcanoes National Park resources use are the weaknesses of the initiative including poor leadership and weak governance of SACOLA. It has been estimated also that $90 \%$ of the world's poorest people depend substantially on forests for their livelihoods' (Scherr et al. 2004) and it has become unfashionable to identify population growth as the cause of environmental problems. However around PNV, $91 \%$ of households are agricultural with an average of less than 1 hectare of land per family of 6-7 people (IGCP, 2008).

More than $90 \%$ of rural people rely on fuel wood for heating water and cooking (MINECOFIN 2002). In most places, this demand is met by local woodlots but there are areas of shortage.

Chi-Square Tests

Table 11: Chi-Square Tests

\begin{tabular}{|l|c|c|c|}
\hline & Value & df & $\begin{array}{l}\text { Asymp. Sig. (. } \\
\text { sided) }\end{array}$ \\
\hline $\begin{array}{l}\text { Pearson Chi- } \\
\text { Square }\end{array}$ & 11.019 & 4 & .026 \\
\hline Likelihood Ratio & 9.669 & 4 & .046 \\
\hline
\end{tabular}

\begin{tabular}{|l|c|c|c|}
\hline $\begin{array}{l}\text { Linear-by-Linear } \\
\text { Association }\end{array}$ & 4.094 & 1 & .043 \\
\hline N of Valid Cases & 72 & & \\
\hline
\end{tabular}

The study found out that more people in SACOLA have a positive attitude towards the use of resources from VNP. Most of these people are satisfied by what they are benefiting from the association even though some are satisfied at a very low and a low level.

There was an association $(\mathrm{P}=0.026$, Pearson ChiSquare) between satisfaction with SACOLA activities and the probability of going into the park and this conduct to the failure to accept the null hypothesis.

\section{CONCLUSION}

This study investigated the contribution of community based organizations in the conservation of VNP, case study of SACOLA in Nyange and Kinigi Sectors. It was limited to different activities of SACOLA through four cooperatives it supports, and its contribution to the VNP conservation.

This study found out that agriculture is the main economic activity generating a lot of income used to sustain the livelihood in the study area, and the crops providing more income are irish potatoes and pyrethrum generating respectively $323583 \mathrm{Rwf}$ and 337037 Rwf as annual mean income.

The research found a significance statistical difference between the frequency of going into the park before and after SACOLA activities. Water is the resources mostly used from Volcanoes National Park before $(48.6 \%)$ and $(8.3 \%)$ after. There have been changes for all resources use after they have joined SACOLA. This explains how the difference is significant, and how much SACOLA have contributed to reduce the pressure on park. It comes from this research that $65.3 \%$ of respondents recognized to be satisfied at a very high level. 
This study recommends the pursuit of similar researches on Community Based Organizations around the Volcanoes National Park. It can be important to undertake a research to know the difference on the perception of local communities living very close to the park $(<5 \mathrm{~km})$ and those far from the park $(5-10 \mathrm{Km}$ and more).

\section{References}

[1].Adams, W. \& Hulme, D. (2001). Community and Conservation: Changing narratives, policies and practices In African conservation. In D. Hulme \& M. Murphree (Eds). African Wildlife and Livelihoods: The promise and performance of community conservation. Oxford: James Currey Ltd.

[2].E.Rutagarama, A. Martin, M.Gray, S.Asuna, M.Bana, A.Basabose, M.Mwine.2008. A report on the experience of community conservation enterprises undertaken by the International Gorilla Conservation Programme

[3].Hackel, D. J. (1999). Community conservation and the future of Africa's wildlife. conservation biology, 13 (4), 726734.

[4].Hulme, D. and M. Murphee. 2001. Community conservation in Africa; an introduction. In Hulme, D.and Murphee, M.(eds.) African Wildlife and livelihoods. Heinemann, Portsmouth, Pages 1-8

[5].IGCP, 2008. IGCP Strategy Document Virunga. Five Year Strategy (20062010).Updated Jan. 2008

[6].Juan, C.2003. Community-based Conservation, participatory conservation in buffer zone communities in the natural protected areas of Chiapas, México, pge 5

[7].Makambo, W. (2009), "Sabyinyo Silverback Lodge: A community partnership for conservation,"International Gorilla

\section{4}

Conservation Program, presentation from RDB-TC tourism forum.

[8].MINECOFIN, 2002. A Profile of Poverty in Rwanda, February 2002, Ministry of Finance and Economic Planning, Rwanda [9]. ORTPN, (2005). Strategic plan 2005-2008 ORTPN, Kigali-Rwanda, pp 26- 178.

[10]. Plumptre, A. (2003). The Socioeconomic Status of People Living near Protected Areas in the Central Albertine Rift, pp 198

[11]. Plumptre, A.J. and Williamson, E.A. (2001). Conservation-oriented research in the virunga region. In Mountain Gorillas: Three decades of research at Karisoke. ed by M.M. Robbins, P.Sicotte and K.J. Stewart, pp. 361-389. University Press,Cambridge.

[12]. SACOLA, (2009). Administration and financial manual of SACOLA

[13]. Scherr S, White A and Kaimowitz D 2004 A new agenda for forest conservation and poverty reduction: making markets work for low-income producers, Forest Trends, Washington, DC 